\title{
Study of System of Crop Intensification (SCI) and Phosphorus Management on Growth, Yield and Economics of Greengram (Vigna radiata L.)
}

\author{
B. M. V. Prasad Swamy ${ }^{1,2 *}$, Vikram Singh $^{3}$, Dhananjay Tiwari ${ }^{3}$ and Indu Thakur ${ }^{3}$ \\ ${ }^{1}$ Department of Agronomy, Sam Higginbottom University of Agriculture, Technology and \\ Sciences, Prayagraj- 211007,Uttar Pradesh, India \\ ${ }^{2}$ Agronomy, Department of Agronomy, ${ }^{3}$ Department of Agronomy, Naini Agricultural Institute \\ SHUATS, Prayagraj (U.P.) India Pin code- 211007 \\ *Corresponding author
}

\section{A B S T R A C T}

\begin{tabular}{l} 
Ke y w o r d s \\
$\begin{array}{l}\text { Green gram, } \\
\text { Plant geometry, } \\
\text { Phosphorus }\end{array}$ \\
\hline Article Info \\
$\begin{array}{l}\text { Accepted: } \\
18 \text { July } 2020 \\
\text { Available Online: } \\
10 \text { August } 2020\end{array}$ \\
\hline
\end{tabular}

A field experiment was conducted during Zaid 2019 at Central Crop Research Farm, Department of Agronomy, SHUATS, Prayagraj (U.P). To study the "System of Crop Intensification (SCI) and Phosphorus management on growth, yield and economics of Greengram (Vigna radiata)". There were 10 treatments each replicated thrice. The treatment consists of 4 different spacing levels of $(20 \mathrm{~cm} \times 20 \mathrm{~cm}),(25 \mathrm{~cm} \times 25 \mathrm{~cm})$, $(30 \mathrm{~cm} \times 30 \mathrm{~cm}),(35 \mathrm{~cm} \times 35 \mathrm{~cm})$ and 2 different sources of application of phosphorus, $100 \%$ RDP through Inorganic, 50\% RDP Inorganic + 50\% Organic.. The experiment was laid out in Randomized Block Design. The results revealed that maximum growth attributes such as plant height $(24.87 \mathrm{~cm})$, number of nodules $(6.80 /$ plant $)$ and dry weight $(4.52 \mathrm{~g} / \mathrm{plant})$ was obtained by application of $\mathrm{T}_{1}:(100 \% \mathrm{RDP}$ through Inorganic $+20 \mathrm{~cm} \times 20 \mathrm{~cm})$ at 60 days after sowing. However maximum Crop growth rate $\left(2.21 \mathrm{~g} / \mathrm{m}^{2} /\right.$ day $)$ at $15-30 D A S$ were recorded with the application of $\mathrm{T}_{9}(100 \%$ RDP through Inorganic (Control) $30 \mathrm{~cm} \times$ $10 \mathrm{~cm})$. As well as significantly maximum yield attributes viz, pods per plant (16.80), grains per pod (10.37), Grain yield $(1113.67 \mathrm{~kg} / \mathrm{ha})$, Stover yield (2556 kg/ha) were recorded under $100 \%$ RDP through Inorganic $+20 \mathrm{~cm} \times 20 \mathrm{~cm}$. However gross return (101778 ₹ ha), Net return (63444 ₹ ha) and B:C ratio (2.70) were showed their superiority with application $\mathrm{T}_{2}(100 \% \mathrm{RDP}$ through Inorganic $+25 \mathrm{~cm} \times 25 \mathrm{~cm})$ as compared to other treatments.

\section{Introduction}

The mung bean (Vigna radiata L.) is under cultivation since pre-historic time in India. It is also known as green gram and serve are a major source of dietary protein for the vast majority of people. Pulses are considered as lifeblood of Agriculture. Pulses occupy a unique position in every farming system viz., main, catch, cover, green manure, intercrop and mix crop. Their inclusion in rotation kept the soil alive and productive. Pulse crops enrich the soil fertility by means of addition of organic matter and fixation of atmospheric nitrogen mediated by root nodule of Rhizobium bacteria. They are the cheapest 
source of quality protein for the human being. It is well known that paucity of protein diet results in malnutrition. In general, pulses have two to three times more protein than the cereals or any other group of plants besides supply of micronutrients, low fat, high dietary fiber and complex carbohydrates.

Spacing plays an important role in contributing to the high yield because thick plant population will not get proper light for photosynthesis and high infestation of diseases. On the other hand very low plant population will also reduce the yield. Due to this reason normal population is necessary for high yield. Advantage of optimum spacing under irrigated conditions is due to reduced competition for light because when the moisture is lacking, light is no longer limiting factor and the advantage of uniform spacing is lost Ihsanullah et al., (2002).

Spacing by maintaining plant population to an optimum level, play an important role in growth and development by affecting plant density and in turn moisture, nutrients and space availability Panwar and Sharma, (2004). Indian soils are poor to medium in available phosphorus. Only about 30 per cent of the applied phosphorus is available for crops and remaining part converted into insoluble phosphorus.

Phosphorus is essential constituent of majority of enzyme which is of great importance in the transformation of energy in carbohydrates metabolism and also in respiration. $\mathrm{P}$ is closely related to cell division and development. Fertilizers play key role for obtaining higher crop production. Phosphorus is one of the major plant nutrients for pulses production. Green gram requires relatively higher quantity of phosphorus and is also sensitive to phosphorus deficiency. Keeping these points in view, a field experiment was conducted to assess the effect of System of
Crop Intensification (SCI) and Phosphorus management on growth, yield and economics of Greengram (Vigna radiata $\mathrm{L}$ ).

\section{Materials and Methods}

The experiment was conducted during the Zaid season 2019, at the Crop Research Farm, Department of Agronomy, (SHUATS), Prayagraj (U.P.) The soil of experimental plot was sandy loam in texture, nearly neutral in soil reaction $(\mathrm{pH} 7.3)$, low in organic carbon $(0.57 \%)$, available $\mathrm{N}(230 \mathrm{~kg} / \mathrm{ha})$, available $\mathrm{P}$ (32.10 kg/ha) and available K (235 kg/ha). The treatment consists of 4 different spacing levels of $(20 \mathrm{~cm} \times 20 \mathrm{~cm}), \quad(25 \mathrm{~cm} \times 25 \mathrm{~cm})$, $(30 \mathrm{~cm} \times 30 \mathrm{~cm}),(35 \mathrm{~cm} \times 35 \mathrm{~cm})$ and 2 different sources of application of phosphorus, $100 \%$ RDP through Inorganic, 50\% RDP Inorganic $+50 \%$ Organic. Whose effect was observed on Greengram. There were 10 treatments each replicated thrice. The experiment was laid out in Randomized Block Design. The crop was sown on $11^{\text {th }}$ April 2019 using a variety Samrat (PDM-84-139) with a seed rate of 20 $\mathrm{kg} / \mathrm{ha}$. The recommended dose of $20 \mathrm{~kg} \mathrm{~N}, 40$ $\begin{array}{llllllll}\mathrm{kg} & \mathrm{P} \& & 20 & \mathrm{~kg} & \mathrm{~K}_{2} \mathrm{O} & \text { per ha was applied }\end{array}$ according to the treatment details through DAP, MOP and Vermicompost. Whole quantity of nitrogen and phosphorus was applied as basal at the time of sowing. Five random plants were selected from each plot to record observations on nodulation and plant growth parameters. Similarly, 5 random plant samples were collected from each plot at the time of harvest for recording observations on plant yield attributing characters. The economics viz., cost of cultivation, gross income, net income and $\mathrm{B}: \mathrm{C}$ ratio was worked out at the prevailing market prices of the inputs and outputs at the time of harvest. Experimental data collected was subjected to statistical analysis by adopting Fishers method of Analysis of Variance (ANOVA) as outlined by Gomez and Gomez (2010). Critical Difference (CD) value was calculated 
whenever the ' $F$ ' test was found significant at $5 \%$ level.

\section{Results and Discussion}

\section{Growth attributes}

The growth parameters like plant height, number of nodules and dry weight was significantly affected by the application of different levels and sources of phosphorus along with different spacing.

\section{Plant height (cm)}

Table 1 revealed that green gram crop fertilized with 100\%RDP through Inorganic and with spacing of $20 \mathrm{~cm} \times 20 \mathrm{~cm}$, significantly resulted maximum plant height $(24.87 \mathrm{~cm})$ which was statistically at par with $100 \%$ RDF through inorganic $+25 \mathrm{~cm} \times 25$ $\mathrm{cm}(24.33 \mathrm{~cm})$ and $100 \%$ RDF through inorganic (Control) $30 \times 10(23.87 \mathrm{~cm})$ at 60 days after sowing.

The increase in plant height may be due to phosphorus encourage formation of new cells, promote plant vigour and hastens leaf development, which help in harvesting more solar energy and better utilization of nitrogen, which help towards higher growth attributes Kumar et al., (2017). The SCI practices had significant effects on plant height $(\mathrm{cm})$. However, an increasing trend with closer geometry level could be noticed. This may be due to the competition between the inter and intra plants for sun light, water, nutrients and space at closer spacing which encouraged self-thinning of branches and enhanced vertical growth rather than horizontal growth (Siddharaju et al., 2010).

\section{Number of nodule per plant}

In the present investigation, number of nodules per plant was increased with increasing crop age upto 45 DAS, thereafter they were decreased to 60 DAS (Table 1) showed that significantly maximum number of nodules per plant (6.80) was recorded in $\mathrm{T}_{1}$ $(100 \%$ RDP through inorganic $+20 \mathrm{~cm} \times 20$ $\mathrm{cm})$ which was statistically at par with $\mathrm{T}_{2}$ $(100 \%$ RDP through Inorganic $+25 \mathrm{~cm} \times 25$ cm) ( 6.37), 100\% RDP through Inorganic + $30 \mathrm{~cm} \times 30 \mathrm{~cm}(5.61), 50 \%$ RDP through Inorganic $+50 \%$ vermicompost $+20 \mathrm{~cm} \times$ $20 \mathrm{~cm}$ (5.88) and 100\% RDP through Inorganic (Control) $30 \mathrm{~cm} \times 10 \mathrm{~cm}(6.13)$.

Such increase in nodulation, root and growth might be due to increase in number of nodules which might have supplied sufficient nitrogen by nitrogen fixation and finally enhance productivity of green gram. Similar results also obtained by Prasad et al., (2014).

\section{Dry weight (g) per plant}

The analysed data presented in (Table 1) shown significant variation among all treatments. At 60 DAS significantly maximum plant dry weight (4.52) was recorded in $\mathrm{T}_{1}(100 \%$ RDP through inorganic $+20 \mathrm{~cm} \times 20 \mathrm{~cm}$ ), which was significantly superior over rest of the treatments except with $\mathrm{T}_{2}(100 \% \mathrm{RDP}$ through Inorganic $+25 \mathrm{~cm}$ $\times 25 \mathrm{~cm})(4.43)$ and $T_{9}(100 \%$ RDP through Inorganic (Control) $30 \mathrm{~cm} \times 10 \mathrm{~cm})(4.17)$.

The plants attained more vigour with phosphorus application due to adequate supply and availability of nitrogen, phosphorus, potassium and spacing in balanced combination, resulting in increased dry weight of the plant.

Better photosynthetic activity due to greater exposure to light and increased availability of nutrients to plants might have also resulted in higher dry weight of the plant. These results are close conformity with Erman et al., (2009) and Pandya et al., (2009). 


\section{Yield and yield attributes}

Yield attributes and yield were also significantly affected by application of different levels and sources of phosphorus along with different spacing.

\section{Number of pods/ plant}

Successive increase in the number of pods per plant of Greengram was observed at harvest showing significant impact of System of crop Intensification (SCI) and phosphorus management respectively (Table 2) represent that significantly superior number of pods per plant (16.80) was recorded in $\mathrm{T}_{1}(100 \% \mathrm{RDP}$ through Inorganic $+20 \mathrm{~cm} \times 20 \mathrm{~cm}$ ). And none of the treatments recorded at par value except $\mathrm{T}_{9}(100 \%$ RDP through Inorganic (Control) $30 \mathrm{~cm} \times 10 \mathrm{~cm}) \quad$ (15.90).Higher number of pods/plant might have been possible due to more vigour and strength attained by the plants as a result of better photosynthetic activities with sufficient availability of light, and supply of nutrients in balanced quantity of the plants at growing stages resulted into a higher length of the pod. The result is confirmed by Nadeem et al., 2003.

\section{Number of seeds per plant}

Significantly superior number of pods per plant (10.37) table 2 was recorded in $\mathrm{T}_{1}$ $(100 \%$ RDP through Inorganic $+20 \mathrm{~cm} \times 20$ $\mathrm{cm})$ which statistically at par with $100 \%$ RDP through Inorganic $+25 \mathrm{~cm} \times 25 \mathrm{~cm}(10.17)$, $100 \%$ RDP through Inorganic $+30 \mathrm{~cm} \times 30 \mathrm{~cm}$ (10.30), 100\%R DP through Inorganic + $35 \mathrm{~cm} \times 35 \mathrm{~cm}(10.03), 100 \%$ RDP through Inorganic (Control) $30 \mathrm{~cm} \times 10 \mathrm{~cm}$ (10.07). Increase in Number of seeds per plant due sufficient availability of nutrients (nitrogen, phosphorus, potassium and spacing) and their absorption by the plants, together with better photosynthetic activity due to proper light and spacing between the plants increased the vigour and plant growth thereby resulting in greater number of seed plant ${ }^{-}$. Similar results also reported by Khan et al., (2017).

\section{Test weight (g)}

Data of test weight showed that significantly maximum test weight was recorded under $100 \%$ RDP through Inorganic $+20 \mathrm{~cm} \times 20 \mathrm{~cm}$ (36.78) (Table 2) which was significantly superior over all other treatments except $100 \%$ RDP through Inorganic $+25 \mathrm{~cm} \times 25 \mathrm{~cm}$ (36.67), 100\%RDP through Inorganic $+35 \mathrm{~cm}$ $\times 35 \mathrm{~cm}(36.20), 50 \%$ RDP through Inorganic $+50 \%$ vermicompost $+25 \mathrm{~cm} \times 25 \mathrm{~cm}$ (36.10), $100 \%$ RDP through Inorganic (Control) $30 \mathrm{~cm} \times 10 \mathrm{~cm}$ (36.23). Higher vigour and growth attained by the plants due to sufficient absorption of nutrients might have resulted in higher test weight. Similar results also reported by Sundara et al., (2004) and Aga et al., (2004).

\section{Grain yield (Kg/ha)}

Table 2 represented that significantly superior grain yield (1113.67) was recorded in $\mathrm{T}_{1}$ $(100 \%$ RDP through Inorganic $+20 \mathrm{~cm} \times 20$ cm) which was statistically at par with $100 \%$ RDP through Inorganic $+25 \mathrm{~cm} \times 25 \mathrm{~cm}$ (1054) and 100\% RDP through Inorganic (Control) $30 \mathrm{~cm} \times 10 \mathrm{~cm}(1060.67$.This might be due to that greater translocation of photosynthates from source to sink might have increased seed yield. Similar conformity has by Balai et al., (2017). Phosphorus increases yield due to its well-developed root system, increased $\mathrm{N}$ fixation and its availability to the plants and favorable environments in the rhizosphere. Also Lokhande et al., (2018) also reported similar results.

\section{Stover yield (Kg/ha)}

Stover yield data showing that significant variation among all treatments. 
Table.1

\begin{tabular}{|c|c|c|c|}
\hline Treatments & $\begin{array}{l}\text { Plant height } \\
(\mathbf{c m})\end{array}$ & Nodules/plant & Dry weight (g) \\
\hline 1. $100 \%$ RDP through Inorganic $+20 \mathrm{~cm} \times 20 \mathrm{~cm}$ & 24.87 & 6.80 & 4.52 \\
\hline 2. $100 \%$ RDP through Inorganic $+25 \mathrm{~cm} \times 25 \mathrm{~cm}$ & 24.33 & 6.37 & 4.43 \\
\hline 3. $100 \%$ RDP through Inorganic $+30 \mathrm{~cm} \times 30 \mathrm{~cm}$ & 17.95 & 5.61 & 3.51 \\
\hline 4. $100 \%$ RDP through Inorganic $+35 \mathrm{~cm} \times 35 \mathrm{~cm}$ & 18.85 & 5.27 & 3.43 \\
\hline $5.50 \%$ RDP through Inorganic $+50 \%$ vermicompost $+20 \mathrm{~cm} \times 20 \mathrm{~cm}$ & 19.89 & 5.88 & 3.60 \\
\hline 6. $50 \%$ RDP through Inorganic $+50 \%$ vermicompost $+25 \mathrm{~cm} \times 25 \mathrm{~cm}$ & 20.86 & 5.70 & 3.78 \\
\hline 7. 50\% RDP through Inorganic $+50 \%$ vermicompost $+30 \mathrm{~cm} \times 30 \mathrm{~cm}$ & 18.60 & 4.99 & 3.68 \\
\hline 8. $50 \%$ RDP through Inorganic $+50 \%$ vermicompost $+35 \mathrm{~cm} \times 35 \mathrm{~cm}$ & 21.42 & 4.78 & 3.77 \\
\hline $9.100 \%$ RDP through Inorganic $($ Control) $30 \mathrm{~cm} \times 10 \mathrm{~cm}$ & 23.87 & 6.13 & 4.17 \\
\hline $\begin{array}{l}10.50 \% \text { RDP through Inorganic }+50 \% \text { vermicompost (Control) } 30 \mathrm{~cm} \\
\times 10 \mathrm{~cm}\end{array}$ & 17.27 & 4.13 & 3.43 \\
\hline F test & $\mathrm{S}$ & $\mathrm{S}$ & $\mathrm{S}$ \\
\hline SEm \pm & 0.89 & 0.47 & 0.21 \\
\hline $\mathrm{CD}(\mathbf{P}=\mathbf{0 . 0 5})$ & 2.65 & 1.41 & 0.62 \\
\hline
\end{tabular}


Table.2

\begin{tabular}{|c|c|c|c|c|c|}
\hline Treatments & $\begin{array}{c}\text { No. of } \\
\text { pods } \\
\text { plant }^{-1}\end{array}$ & $\begin{array}{l}\text { No. of } \\
\text { grains } \\
\text { pod }^{-1}\end{array}$ & $\begin{array}{c}\text { Test } \\
\text { weight } \\
\text { (g) }\end{array}$ & $\begin{array}{c}\text { Grain } \\
\text { yield } \\
\left(\mathrm{kg} \mathrm{ha}^{-1}\right)\end{array}$ & $\begin{array}{c}\text { Stover } \\
\text { yield } \\
\left(\mathrm{kg} \mathrm{ha}^{-1}\right)\end{array}$ \\
\hline $1.100 \%$ RDP through Inorganic $+20 \mathrm{~cm} \times 20 \mathrm{~cm}$ & 16.80 & 10.37 & 36.78 & 1113.67 & 2556 \\
\hline 2. $100 \%$ RDP through Inorganic $+25 \mathrm{~cm} \times 25 \mathrm{~cm}$ & 15.77 & 10.17 & 36.67 & 1054 & 2251 \\
\hline 3. $100 \%$ RDP through Inorganic $+30 \mathrm{~cm} \times 30 \mathrm{~cm}$ & 15.00 & 10.30 & 35.60 & 786 & 1650 \\
\hline 4. $100 \%$ RDP through Inorganic $+35 \mathrm{~cm} \times 35 \mathrm{~cm}$ & 15.40 & 10.03 & 36.20 & 781 & 1606 \\
\hline $5.50 \%$ RDP through Inorganic $+50 \%$ vermicompost $+20 \mathrm{~cm} \times 20 \mathrm{~cm}$ & 13.63 & 9.87 & 35.67 & 821.33 & 1808 \\
\hline 6. $50 \%$ RDP through Inorganic $+50 \%$ vermicompost $+25 \mathrm{~cm} \times 25 \mathrm{~cm}$ & 13.87 & 9.93 & 36.10 & 776 & 1637 \\
\hline 7. 50\% RDP through Inorganic $+50 \%$ vermicompost $+30 \mathrm{~cm} \times 30 \mathrm{~cm}$ & 13.53 & 9.77 & 35.94 & 705 & 1564 \\
\hline 8. $50 \%$ RDP through Inorganic $+50 \%$ vermicompost $+35 \mathrm{~cm} \times 35 \mathrm{~cm}$ & 13.03 & 9.57 & 35.87 & 700 & 1531.67 \\
\hline $9.100 \%$ RDP through Inorganic $($ Control) $30 \mathrm{~cm} \times 10 \mathrm{~cm}$ & 15.90 & 10.07 & 36.23 & 1060.67 & 2424 \\
\hline $\begin{array}{l}10.50 \% \text { RDP through Inorganic }+50 \% \text { vermicompost }(\text { Control) } 30 \mathrm{~cm} \times \\
10 \mathrm{~cm}\end{array}$ & 13.07 & 9.63 & 35.70 & 854 & 1926 \\
\hline F test & $\mathrm{S}$ & $\mathrm{S}$ & $\mathrm{S}$ & $\mathrm{S}$ & $\mathrm{S}$ \\
\hline SEm \pm & 0.33 & 0.14 & 0.24 & 28.89 & 43.18 \\
\hline $\mathrm{CD}(\mathrm{P}=\mathbf{0 . 0 5})$ & 0.98 & 0.40 & 0.72 & 85.83 & 128.28 \\
\hline
\end{tabular}


Table. 3

\begin{tabular}{|c|c|c|c|}
\hline Treatments & $\begin{array}{l}\text { Gross return } \\
\quad\left(\mathrm{Rs} \mathrm{ha}^{-1}\right)\end{array}$ & $\begin{array}{c}\text { Net return } \\
\left(\mathrm{Rs} \mathrm{ha}^{-1}\right)\end{array}$ & $\begin{array}{l}\text { B:C } \\
\text { Ratio }\end{array}$ \\
\hline 1. $100 \%$ RDP through Inorganic $+20 \mathrm{~cm} \times 20 \mathrm{~cm}$ & 101778 & 63444 & 2.66 \\
\hline 2. $100 \%$ RDP through Inorganic $+25 \mathrm{~cm} \times 25 \mathrm{~cm}$ & 95985 & 60497.1 & 2.70 \\
\hline 3. $100 \%$ RDP through Inorganic $+30 \mathrm{~cm} \times 30 \mathrm{~cm}$ & 71625.1 & 34247.1 & 1.92 \\
\hline 4. $100 \%$ RDP through Inorganic $+35 \mathrm{~cm} \times 35 \mathrm{~cm}$ & 71093 & 31775 & 1.81 \\
\hline $5.50 \%$ RDP through Inorganic $+50 \%$ vermicompost $+20 \mathrm{~cm} \times 20 \mathrm{~cm}$ & 74824.3 & 40271.33 & 2.17 \\
\hline 6. 50\% RDP through Inorganic $+50 \%$ vermicompost $+25 \mathrm{~cm} \times 25 \mathrm{~cm}$ & 70658.5 & 35150.50 & 1.99 \\
\hline 7. 50\% RDP through Inorganic $+50 \%$ vermicompost $+30 \mathrm{~cm} \times 30 \mathrm{~cm}$ & 64232 & 20178 & 1.46 \\
\hline 8. $50 \%$ RDP through Inorganic $+50 \%$ vermicompost $+35 \mathrm{~cm} \times 35 \mathrm{~cm}$ & 63795.3 & 27702 & 1.77 \\
\hline $9.100 \%$ RDP through Inorganic $($ Control) $30 \mathrm{~cm} \times 10 \mathrm{~cm}$ & 96672 & 58084 & 2.51 \\
\hline $\begin{array}{l}10.50 \% \text { RDP through Inorganic }+50 \% \text { vermicompost }(\text { Control }) 30 \mathrm{~cm} \\
\times 10 \mathrm{~cm}\end{array}$ & 77823.17 & 44225.17 & 2.32 \\
\hline
\end{tabular}


Maximum (Table 2) stover yield was obtained under $100 \%$ RDP through Inorganic $+20 \mathrm{~cm} \times$ $20 \mathrm{~cm}(2556 \mathrm{~kg} / \mathrm{ha})$ and none of treatments recorded at par value. The increase in stover yield due to phosphorus application is attributed to source and sink relationship. It appears that greater translocation of photosynthates from source to sink might have increased yield. Balai et al., (2017) also reported similar findings.

\section{Economics}

The highest gross (₹ 101778/ha) and net returns (₹ 63444/ha) were obtained in Green gram fertilized with $100 \%$ RDP through Inorganic and with spacing of $20 \mathrm{~cm} \times 20 \mathrm{~cm}$. Where, as the higher $\mathrm{B}: \mathrm{C}$ ratio (2.70) were obtained in Green gram fertilized with $100 \%$ RDP through Inorganic and with spacing of $25 \mathrm{~cm} \times 25 \mathrm{~cm}$ (Table 3 ). The increase in gross returns and net returns of Green gram crop in the same unit area obtained from $100 \%$ RDP through Inorganic and with spacing of $20 \mathrm{~cm} \times 20 \mathrm{~cm}$ because of optimum fertilizer doses are along with huge plant population available for the crop and moreover, the increase in spacing results in higher $\mathrm{B}: \mathrm{C}$ ratio when fertilized with $100 \%$ RDP through Inorganic along with spacing of $25 \mathrm{~cm} \times 25 \mathrm{~cm}$, because of lesser competition for available nutrients between the plants with lesser plant population

It is concluded, on the basis of one year experiment, application of 100\%RDP through Inorganic along with a spacing of $20 \mathrm{~cm} \times 20$ $\mathrm{cm}$ is more productive whereas $100 \% \mathrm{RDP}$ through Inorganic along with a spacing of $25 \mathrm{~cm} \times 25 \mathrm{~cm}$ was economically effective.

\section{Acknowledgement}

I express gratitude to my advisor Dr. Vikram Singh for constant support and guidance. I am indebted to Prof. (Dr.) Thomas Abraham and
Prof. (Dr.) Joy Dawson and all the faculty members of SHUATS for inspiration.

\section{References}

Aga, F.A., Singh, J.K., Singh, D.K. and Peer, F.A. 2004. Effect of different levels of compost and phosphorous on growth and yield of pea (Pisum sativum L.) under rainfed condition. Environmental and Ecology. 22(2): 653-356.

Balai, K., Jajoria, M., Verma, R., Deewan, P., Barwa, S. K. 2017. Nutrient content, uptake, quality of chickpea and fertility status of soil influenced by fertilization of phosphorus and zinc .Journal of pharmacy practice, 6(1):392-398.

Erman, M. Yildirm, Btogay, N. cig F. 2009.Effect of phosphorus application and Rhizobium inoculation on the yield, nodulation and nutrient uptake in field pea (Pisum sativums L.). Journal of Animal and Veterinary Advances 8(2): 301-304.

Gomez, K.A., Gomez A.A. 2010. Statistical procedures for agricultural research. 2nd edn. Wiley India Pvt Ltd, India.

Ihsanullah, T.F.H. Akbar, H. Basir, A. and Ulaah, N. 2002. Effect of row spacing on agronomic traits and yield of mungbean (Vigna radiata L.). Asian Journal of Plant Sciences, 1(4): 328329.

Khan, M.MD, S., Singh, V.P. and Kumar, A. 2017. Studies on Effect of Phosphorous Levels on Growth and Yield of Kharif Mungbean (Vigna radiata L. wilczek). Int. J. Pure App. Biosci. 5 (4): 800-808.

Kumar, S., Tomar, S and Tomar, T.S. 2017. Integrated phosphorus management in black gram (Vigna mungo) in western Uttar Pradesh during summer season. Annals of Agricultural Research. 35(3): 290-297.

Lokhande, P.B., Indulkar, B.S., Vaidya, P.H., Padghan, A.D., Wagh, C.B., Ingole, 
A.J., Patil, N.M. and Aundhkar A. V. 2018. Effect of Phosphorus and Zinc on Yield and Quality of Green Gram (Vigna Radiata L.) in Inceptisol. International Journal of Engineering Science and Computing, 8(7):1864718649.

Nadeem, A., Amjad, $\mathrm{M}$ and Anjum, M.A .2003. Growth and Yield Response of Pea (Pisum sativum L.) Crop to Phosphorus and Potassium Application. Pakisthan Journal of Agriculture Sciences., 40(3-4): 217-222.

Panwar, G. and Sharma, B.B. 2004. Effect of planting date, seed rate and row spacing on yield and yield attributes of bold seeded mungbean during summer season. Indian Journal of Pulses Research, 17(1): 45-46.
Prasad, S. K., Singh, M. K. and Singh, J. 2014. Response of rhizobium inoculation and phosphorus levels on mungbean (Vigna radiata L.) under guava-based agri-horti system. The Bioscan, 9: 557-560.

Siddaraju, R., Narayanaswamy, S., Ramegowda and Prasad, S. R. 2010. Studies on growth, seed yield and yield attributes as influenced by varieties and row spacing in cluster bean (Cyamopsis tetragonoloba L.). Mysore Journal of Agriculture Science, 44:16-21.

Sundara, T.H., Vyakaranahal, B. S., Shekharguoda, M., Sashidhara, S.D. and Hosamani, R.M. 2004.Influence of phosphorous and micronutrient on seed yield and quality of pea (Pisum sativum L.). Seed Research, 32(2): 214-216.

\section{How to cite this article:}

Prasad Swamy, B.M.V., Vikram Singh, Dhananjay Tiwari and Indu Thakur. 2020. Study of System of Crop Intensification (SCI) and Phosphorus Management on Growth, Yield and Economics of Greengram (Vigna radiata L.). Int.J.Curr.Microbiol.App.Sci. 9(08): 1950-1958. doi: https://doi.org/10.20546/ijcmas.2020.908.223 